\title{
Holocephalocotyle monstrosae n. gen. n. sp. (Monogenea, Monocotylidae) from the olfactory rosette of the rabbit fish, Chimaera monstrosa (Holocephali, Chimaeridae) in deep waters off Algeria
}

\author{
Imane Derouiche ${ }^{1}$, Lassad Neifar ${ }^{2, *}$, Delphine Gey $^{3}$, Jean-Lou Justine ${ }^{4, *}$, and Fadila Tazerouti ${ }^{1}$ \\ ${ }^{1}$ Université des Sciences et de la Technologie Houari Boumediene (U.S.T.H.B), Faculté des Sciences Biologiques, Département \\ d'Écologie et Environnement, Laboratoire de Biodiversité et Environnement : Interactions et Génomes, Équipe 1 : Parasites : \\ Biodiversité-Bioécologie-Interactions Hôtes-Parasites, BP 32, El Alia Bab Ezzouar, 16111 Alger, Algeria \\ ${ }^{2}$ Laboratoire de Biodiversité Marine et Environnement, Faculté des Sciences de Sfax, Université de Sfax, BP 1171, 3038 Sfax, Tunisia \\ ${ }^{3}$ Institut Systématique Évolution Biodiversité (ISYEB), Muséum National d'Histoire Naturelle, CNRS, Sorbonne Université, EPHE, \\ Université des Antilles, 57 rue Cuvier, CP 51, 75005 Paris, France \\ ${ }^{4}$ Service de Systématique Moléculaire, UMS 2700 CNRS, Muséum National d'Histoire Naturelle, CP 26, 43 Rue Cuvier, 75231 Paris \\ Cedex 05, France
}

Received 27 April 2019, Accepted 9 September 2019, Published online 20 September 2019

\begin{abstract}
Based on a molecular and morphological study, a new monocotylid genus, Holocephalocotyle n. gen. is proposed to accommodate Holocephalocotyle monstrosae n. sp., found on the olfactory rosette of the rabbit fish, Chimaera monstrosa Linnaeus (Chondrichthyes, Chimaeridae), from the Mediterranean Sea off Algeria. Identification of fish hosts was confirmed by molecular barcoding of the COI gene. A partial 28S rDNA sequence (D1-D2 domain) of Holocephalocotyle monstrosae was obtained; it was distinct from all known monocotylid sequences ( $p$-distance: 15.5-23\%). A phylogenetic tree constructed from available monocotylid sequences showed that Holocephalocotyle monstrosae was included, and basal, in a robust group including species of Merizocotyle, Mycteronastes and Empruthotrema, confirming that the species is a member of the Merizocotylinae. The new genus is unique among the Merizocotylinae in having a distinctive pattern of haptoral loculi with one central, five peripheral and seven "interperipheral loculi" partially inserted between peripheral loculi and a compartmentalised sclerotised male copulatory organ. The diagnosis of the Merizocotylinae is amended to include this new genus. The new genus represents the second monocotylid genus recorded from holocephalans.
\end{abstract}

Key words: Chimaeridae, Monocotylidae, Holocephalocotyle n. gen., 28S rDNA, Mediterranean.

Résumé - Holocephalocotyle monstrosae n. gen. n. sp. (Monogenea, Monocotylidae) de la rosette olfactive de la chimère Chimaera monstrosa (Holocephali, Chimaeridae) en mer profonde au large de l'Algérie. Sur la base d'une étude moléculaire et morphologique, un nouveau genre de Monocotylidae, Holocephalocotyle n. gen. est proposé pour accueillir Holocephalocotyle monstrosae n. sp., trouvé sur la rosette olfactive de la chimère Chimaera monstrosa Linnaeus (Chondrichthyes, Chimaeridae) de la mer Méditerranée au large de l'Algérie. L'identification des hôtes poissons a été confirmée par code-barre moléculaire du gène COI. Une séquence partielle d'ADNr $28 \mathrm{~S}$ (domaine D1-D2) d'Holocephalocotyle monstrosae a été obtenue et était distincte de toutes les séquences de Monocotylidae connues ( $p$-distance : 15.5-23\%). Un arbre phylogénétique construit à partir des séquences de Monocotylidae disponibles a montré qu'Holocephalocotyle monstrosae était inclus et basal dans un groupe robuste comprenant des espèces de Merizocotyle, Mycteronastes et Empruthotrema, confirmant que l'espèce est membre des Merizocotylinae. Le nouveau genre est unique parmi les Merizocotylinae en ce qu'il présente un motif distinctif de loculi haptoraux avec un loculus central, 5 périphériques et 7 « loculi intra-périphériques » partiellement insérés entre des loculi périphériques, et un organe copulateur mâle sclérifié compartimenté. La diagnose des Merizocotylinae est modifiée pour inclure ce nouveau genre. Le nouveau genre représente le deuxième genre de Monocotylidae répertorié chez les holocéphales.

*Corresponding authors: lassad.neifar@gmail.com; justine@mnhn.fr 


\section{Introduction}

The Holocephali or chimaerid fishes form a small and enigmatic subclass of Chondrichthyes, hypothetically diverged from a common ancestor with the elasmobranch fishes about 413 Ma ago [27]. Holocephalans are hosts of unique parasite groups including the Chimaericolidae (Monogenea) and the Gyrocotylidea (Cestoda). The rabbit fish, Chimaera monstrosa, occurring in the eastern Atlantic Ocean and Mediterranean Sea, is the most studied species among holocephalans [16, 18, 23, $36,40]$. Among metazoan parasites, only two monogeneans were reported from this fish namely, Chimaericola leptogaster (Leuckart, 1830) (Chimaericolidae) from the gills and Calicotyle affinis Scott, 1911 (Monocotylidae) from the cloaca. However, the olfactory organ has been neglected in previous parasitological examinations; this site could represent, as for numerous elasmobranchs, a potential site for the discovery of new species of monogeneans.

During a collaborative study of the helminth parasites of chondrichthyan hosts of Algeria (western Mediterranean), a species of the Merizocotylinae Johnston and Tiegs, 1922 was recovered from the olfactory chamber of the rabbit fish. In the present study, integrative taxonomy based on molecular and morphological analyses was used to provide a formal description of a new species and the proposal of a new genus for its accommodation. This paper belongs to a series of papers dealing with the morphological and molecular description of monogeneans from off the southern Mediterranean coast [2-7, 22].

\section{Materials and methods}

\section{Collection of host and parasite material}

Between December 2013 and January 2018, a total of 231 specimens of rabbit fish, Chimaera monstrosa $(7-50 \mathrm{~cm}$ in length; 9-1500 $\mathrm{g}$ in weight), were collected from five fishing ports in Algeria: 197 from Cherchell $\left(36^{\circ} 36^{\prime} 31^{\prime \prime} \mathrm{N}, 2^{\circ}\right.$ $\left.11^{\prime} 50^{\prime \prime} \mathrm{E}\right), 15$ from Bouharoun $\left(36^{\circ} 37^{\prime} 55^{\prime \prime} \mathrm{N}, 02^{\circ} 39^{\prime} 35^{\prime \prime} \mathrm{E}\right)$, 10 from El Djamila $\left(36^{\circ} 48^{\prime} 01^{\prime \prime} \mathrm{N}, 2^{\circ} 54^{\prime} 05^{\prime \prime} \mathrm{E}\right), 5$ from Annaba $\left(36^{\circ} 54^{\prime} 11^{\prime \prime} \mathrm{N}, 07^{\circ} 47^{\prime} 03^{\prime \prime} \mathrm{E}\right)$ and 4 from Beni Saf $\left(01^{\circ} 10^{\prime} 23^{\prime \prime} \mathrm{W}\right.$, $\left.35^{\circ} 10^{\prime} 18^{\prime \prime} \mathrm{N}\right)$. The fish were caught during commercial shrimp trawl fishery as bycatch.

All fish caught were dissected shortly after capture and examined for parasites in the laboratory. The olfactory chamber was entirely removed and placed in Petri dishes filled with filtered sea water. The olfactory rosette was scraped out carefully, under a stereomicroscope and monogeneans were removed from the mucus with the help of a dissection needle and aspirated with a pipette. Some living specimens were narcotised with menthol crystal in a 5-10\% solution [28], before fixation, to unfold the haptor.

\section{Molecular analysis}

\section{Molecular barcoding of host fish}

For two individual fish, total genomic DNA was isolated from absolute ethanol fixed olfactory lamellae using a QIAamp DNA Mini Kit, as per the manufacturer's instructions. The $5^{\prime}$ region of the mitochondrial cytochrome $c$ oxidase (COI) subunit I gene was amplified with the primers FishF1 (5'-TCAACCAACCACAAAGACATTGGCAC-3') and FishR1 (5'-TAGACTTCTGGGTGGCCAAAGAATCA-3') [39]. PCR reactions were performed in $20 \mu \mathrm{L}$, containing $1 \mathrm{ng}$ of DNA, $1 \times$ CoralLoad PCR buffer, $3 \mathrm{mM} \mathrm{MgCl} 2,66 \mu \mathrm{M}$ of each dNTP, $0.15 \mu \mathrm{M}$ of each primer, and 0.5 units of Taq DNA polymerase (Qiagen). The amplification protocol was $4 \mathrm{~min}$ at $94{ }^{\circ} \mathrm{C}$, followed by 40 cycles at $94{ }^{\circ} \mathrm{C}$ for $30 \mathrm{~s}, 48{ }^{\circ} \mathrm{C}$ for $40 \mathrm{~s}$, and $72{ }^{\circ} \mathrm{C}$ for $50 \mathrm{~s}$, with a final extension at $72{ }^{\circ} \mathrm{C}$ for 7 min. PCR products were purified (Ampure XP Kit, Beckman Coulter) and sequenced in both directions on a 3730xl DNA Analyzer 96-capillary sequencer (Applied Biosystems). We used CodonCode Aligner version 3.7.1 software (CodonCode Corporation, Dedham, MA, USA) to edit sequences, which were $651 \mathrm{bp}$ in length, compared them to the GenBank database content with BLAST, and deposited them in GenBank under accession numbers MN397913 and MN397914. Species identification was confirmed with the BOLD identification engine [41].

\section{Molecular analysis of monogeneans}

DNA was extracted using a QiaAmp DNA Micro kit (Qiagen). A 28S rDNA fragment of $884 \mathrm{bp}$ was amplified using the universals primers $\mathrm{Cl}^{\prime}\left(5^{\prime}\right.$-ACCCGCTGAATTTAAGCAT-3') and D2 (3'-TCCGTGTTTCAAGACGG-5') [19]. PCR reactions were performed in a final volume of $20 \mathrm{~mL}$, containing: $1 \mathrm{ng}$ of DNA, 16CoralLoad PCR buffer, $3 \mathrm{mM} \mathrm{MgCl}_{2}$, $66 \mathrm{mM}$ of each dNTP, $0.15 \mathrm{mM}$ of each primer, and 0.5 units of Taq DNA polymerase (Qiagen). Thermocycles consisted of an initial denaturation step at $94^{\circ} \mathrm{C}$ for $1 \mathrm{~min}$, followed by 40 cycles of denaturation at $94^{\circ} \mathrm{C}$ for $30 \mathrm{~s}$, annealing at $60^{\circ} \mathrm{C}$, for $30 \mathrm{~s}$, and extension at $72{ }^{\circ} \mathrm{C}$ for $1 \mathrm{~min}$. The final extension was conducted at $72{ }^{\circ} \mathrm{C}$ for $7 \mathrm{~min}$. PCR products were visualised on a $1.5 \%$ agarose gel, purified and directly sequenced in both directions on a 3730xl DNA Analyzer 96-capillary sequencers (Applied Biosystems) at Eurofins Genomics. Sequences were edited and assembled using CodonCode Aligner software (CodonCode Corporation, Dedham, MA, USA), and compared to the GenBank database content with BLAST. Sequences from three individual monogeneans were obtained and were found to be identical; they were deposited in GenBank under accession number MN412655-MN412657.

\section{Trees of monogeneans and distances}

A tree was constructed from our new sequence and $28 \mathrm{~S}$ sequences of monocotylids (Table 1). We used almost all sequences available in GenBank, with the exception of sequences that were too short, such as those of Loimosina sp. (KF908848), Potamotrygonocotyle tsalickisi (JN379513), and Calicotyle affinis (AF382061), the latter of which did not align well (but five other species of Calicotyle were included in the analysis); a sequence of the microbothriid Leptocotyle minor was used as the outgroup. The dataset included 32 nucleotide sequences. Both extremities of sequences were trimmed to obtain a clean matrix and thus there were 744 positions in the 
Table 1. Species of the Monocotylidae used in the molecular analysis.

\begin{tabular}{|c|c|c|c|c|}
\hline$\underline{\text { Parasite species }}$ & Host species & Site & Locality & GenBank ID \\
\hline Holocephalocotyle monstrosae & Chimaera monstrosa & Olfactory rosette & Algeria, Mediterranean Sea & MN412655-MN412657 \\
\hline Calicotyle kroyeri & Raja radiata & Cloaca & North Sea & AF279746 \\
\hline Calicotyle palombi & Mustelus mustelus & Cloaca & Tunisia, Mediterranean Sea & AF279749 \\
\hline Calicotyle stossichi & Mustelus mustelus & Rectal gland & Tunisia, Mediterranean Sea & AF279751 \\
\hline Calicotyle urolophi & Urolophus cruciatus & Cloaca & Tasmania, Australia & AF279752 \\
\hline Calicotyle japonica & Squalus mitsukurii & Cloaca & Pacific & AB485996 \\
\hline Dictyocotyle coeliaca & Raja radiata & $\begin{array}{l}\text { Inner wall } \\
\text { of body cavity }\end{array}$ & North Sea & AF279754 \\
\hline Empruthotrema dasyatidis & Orectolobus maculatus & Nasal tissue & Heron Island, Australia & AF348345 \\
\hline Empruthotrema quindecima & Taeniura lymma & Nasal tissue & Heron Island, Australia & AF348346 \\
\hline Merizocotyle urolophi & Urolophus bucculentus & Nasal tissue & Tasmania, Australia & AF348347 \\
\hline Merizocotyle australensis & Himantura fai & Nasal tissue & Heron Island, Australia & AF348348 \\
\hline Merizocotyle sinensis & unknown & unknown & unknown & FJ514075 \\
\hline Mycteronastes icopae & Rhinobatos typus & Nasal tissue & Heron Island, Australia & AF348349 \\
\hline Clemacotyle australis & Aetobatus narinari & Gills & Heron Island, Australia & AF348350 \\
\hline Dendromonocotyle ardea & Pastinachus sephen & Dorsal skin & Heron Island, Australia & AF348351 \\
\hline Dendromonocotyle octodiscus & $\begin{array}{l}\text { Dasyatis americana } \\
\text { Urobatis jamaicensis }\end{array}$ & Dorsal skin & Gulf of Mexico, Mexico & AF348352 \\
\hline Monocotyle corali & Pastinachus sephen & Gills & Heron Island, Australia & AF348353 \\
\hline Monocotyle helicophallus & Himantura fai & Gills & Heron Island, Australia & AF348355 \\
\hline Monocotyle spiremae & Himantura fai & Gills & Heron Island, Australia & AF348354 \\
\hline Monocotyle multiparous & Himantura fai & Gills & Heron Island, Australia & AF348356 \\
\hline Decacotyle floridana & Aetobatus narinari & Gills & Heron Island, Australia & AF348357 \\
\hline Decacotyle tetrakordyle & Pastinachus sephen & Gills & Heron Island, Australia & AF348358 \\
\hline Decacotyle lymmae & Aetobatus narinari & Gills & Heron Island, Australia & AF348359 \\
\hline Heterocotyle capricornensis & Himantura fai & Gills & Heron Island, Australia & AF348360 \\
\hline Neoheterocotyle rhinobatidis & Rhinobatos typus & Gills & Heron Island, Australia & AF348361 \\
\hline Neoheterocotyle rhinobatis & Rhynchobatus djiddensis & Gills & Heron Island, Australia & AF348362 \\
\hline Neoheterocotyle rhynchobatis & Rhinobatos typus & Gills & Heron Island, Australia & AF348363 \\
\hline Troglocephalus rhinobatidis & Rhinobatos typus & Gills & Heron Island, Australia & AF348364 \\
\hline Electrocotyle whittingtoni & Narke capensis & Gills & South Africa & KT735368 \\
\hline Potamotrygonocotyle dromedarius & Potamotrygon motoro & Gills & Brazil & JN379518 \\
\hline Potamotrygonocotyle chisholmae & Potamotrygon motoro & Gills & Brazil & JN379519 \\
\hline Leptocotyle minor & Scyliorhinus canicula & Skin & North Sea & AF382063 \\
\hline
\end{tabular}

dataset. After estimating the best model with MEGA7 [26], the tree was inferred using the Maximum Likelihood method based on the General Time Reversible model [32] with gamma distribution and invariant sites (GTR + G + I) in MEGA7 [26], with 200 replications. The neighbour-joining method was also used for comparison in MEGA7, with bootstrap calculated on 2000 replicates. Distances between sequences ( $p$-distances) were computed from the same dataset with MEGA7 [26].

\section{Morphological analysis}

Five specimens were prepared as whole mounts in Malmberg solution $(m)$ [29] to study the morphology of anchors and the male copulatory organ. Forty specimens were flattened under slight coverslip pressure and fixed in $70 \%$ ethanol and thereafter stained with acetic carmine (c) before being dehydrated in a graded ethanol series, cleared in clove oil, and permanently mounted in Canada balsam.

Measurements were obtained using drawing tube and ruler calibrated using a microscopic graduated slide. They represent straight-line distances between extreme points.
Measurements are in micrometers, and indicated as means \pm standard deviation (if $n>30$ ), and between parentheses the range and number (n) of structures measured. Because measured lengths may vary depending on how specimens are prepared and the degree to which they are flattened [2, 21], they are given separately for specimens mounted respectively in Malmberg's medium $(\mathrm{m})$ or stained in carmine and mounted in Canada balsam $(c)$.

Drawings of the parasite were made using a Leitz microscope equipped with a drawing tube and redrawn afterwards on a computer with Adobe Illustrator. Terminology of the olfactory organ of Chimaera monstrosa follows that described by [17]. Haptoral terminology follows that presented and illustrated by $[11,25]$.

The term uncinuli (singular uncinulus) is used for marginal hooklets after Pariselle \& Euzet (1995) [37]. Uncinuli numbering follows that proposed by Kritsky et al. (2017) [25]. We propose the term interperipheral loculi for the loculi partially inserted between peripheral loculi in the haptor. Type specimens of the new taxa were deposited in the Collections of the Muséum National d'Histoire Naturelle (MNHN), Paris. 


\section{Results}

\section{Molecular analysis}

\section{Molecular identification of fish}

The provisional identification of fish species using morphological characteristics was reconfirmed by a DNA barcoding approach. BLAST analysis of the COI sequences of sequences of two host fish specimens with NCBI and BOLD database showed sequence similarity values of, respectively $99.38 \%$ and $100 \%$ with Chimaera monstrosa. The BOLD database [41] includes many sequences with published information for this species and we are thus confident that the identification is valid.

\section{Phylogenetic analysis of monogeneans from $28 \mathrm{~S}$ sequences}

In our dataset, the genetic distance between our new sequences and all monocotylid sequences ranged from $15.5 \%$ to $23 \%$, with the closest sequence being Empruthotrema dasyatidis $(15.5 \%)$ and the most different sequences being Dendromonocotyle ardea (23\%); this clearly showed that our species is different from all other sequenced monocotylid species.

A tree built from 32 sequences, with Leptocotyle minor (Microbothriidae) as the outgroup and 31 monocotylid sequences including the new sequence from our species (Table 1), provided the following results (Fig. 1). There was a total of 744 positions in the final dataset. The general topology of the tree, constructed with the Maximum Likelihood method, showed general agreement with the classification of species into genera, with most genera monophyletic; however, some nodes showed low support. A branch of the tree included species of Merizocotyle, Mycteronastes and Empruthotrema (three genera which are members of the Merizocotylinae) and our new sequence. An analysis based on the NJ method (not shown) showed a slightly different topology of the tree but the Merizocotylinae clade was also clearly defined. Support for the monophyly of the Merizocotylinae clade was high (78\% of trees with ML, bootstrap 78 with $\mathrm{NJ}$ ), strongly suggesting that our new species is a member of the subfamily Merizocotylinae. Within this clade, the new species is sistergroup to a clade including all other species (three members of Merizocotyle, one Mycteronastes and two members of Empruthotrema). Within this clade, members of Merizocotyle apparently do not constitute a monophylum, with Merizocotyle sinensis being a sister-group of Mycteronastes icopae.

\section{Amended diagnosis of Merizocotylinae Johnston \& Tiegs, 1922}

With characters of family Monocotylidae Taschenberg, 1879 (sensu Chisholm, Wheeler \& Beverley-Burton [11]). Haptor with one central loculus (absent or replaced by a central depression in Mycteronastes), one to four interhamular loculi (sensu Kritsky et al. [24]) and four to seven peripheral loculi. Interperipheral loculi sometimes present. Marginal loculi usually present. Haptor rarely with three loculi or numerous unevenly distributed loculi. Fourteen marginal uncinuli. Three prominent apertures from glands containing needle-like secretion on each side of anterior end. Intestinal caeca unbranched, not confluent posteriorly. Testes single, ovoid. Male copulatory organ (MCO) sclerotised (except in Mycteronastes undulatae and Mycteronastes caalusi). Ovary not lobed at blind end. Two vaginae; walls of vaginae not sclerotised. Parasites of fishes of Elasmobranchii and Holocephali.

Type genus: Merizocotyle Cerfontaine, 1894.

Additional genera: Cathariotrema Johnston and Tiegs, 1922; Empruthotrema Johnston and Tiegs, 1922, Mycteronastes Kearn \& Beverley-Burton, 1990, Squalotrema Kearn and Green, 1983; Thaumatocotyle Odhner, 1910, Triloculotrema Kearn, 1993; and Holocephalocotyle.

\section{Holocephalocotyle n. gen.}

Zoobank: urn:1sid:zoobank.org:act:80808F18-10D7-4CD2974C-C6A10DB55F96

With characters of family Monocotylidae (sensu Chisholm et al. [11]), and subfamily Merizocotylinae. Haptor with one central, five peripheral and seven interperipheral loculi partially inserted between peripheral loculi. Seven pairs of marginal uncinuli. Male copulatory organ with muscular bulb. Parasites of the nasal tissue of Chimaeridae.

Etymology: The generic name was constructed based on the name of the subclass of the host (Holocephali) and the ending - cotyle. Gender: feminine.

\section{Holocephalocotyle monstrosae n. sp. (Fig. 2)}

Zoobank: urn:lsid:zoobank.org:act:153B8EF4-AA14-48BC-BC A6-1E8DD614E3C4

Type host: Chimaera monstrosa Linnaeus (Chimaeriformes: Chimaeridae).

Type locality: El Djamila port $\left(36^{\circ} 48^{\prime} 01^{\prime \prime} \mathrm{N}, 2^{\circ} 54^{\prime} 05^{\prime \prime} \mathrm{E}\right)$, Algeria.

Other locality: Cherchell port $\left(36^{\circ} 36^{\prime} 31^{\prime \prime} \mathrm{N}, 2^{\circ} 11^{\prime} 50^{\prime \prime} \mathrm{E}\right)$, Algeria.

Site on the host: Olfactory lamellae.

Type material: Holotype (MNHN HEL1105) and 11 paratypes (MNHN HEL1106-HEL1116).

Molecular sequence data: The 884 bp ribosomal DNA sequences covering the D1-D2 domains of the 28S rDNA gene of three specimens were deposited in GenBank under accession numbers MN412655-MN412657. The individual monogenean barcoded as MN412656 was from the individual fish barcoded as MN397913.

Prevalence: $43 \%(n=231)$; abundance: 0.49 ; maximum intensity: 6.

Etymology: The species is named after the Latin specific name of the host, "monstrosa".

\section{Description}

Based on 40 specimens in carmine (c) and five specimens in Malmberg solution $(m)$. Body length $1398 \pm 368$ (1230-1970, $n=40)(c), 1808(1350-2400, n=5)(m)$ long, including haptor; maximum width $315 \pm 60(200-480, n=40)(c), 422$ 


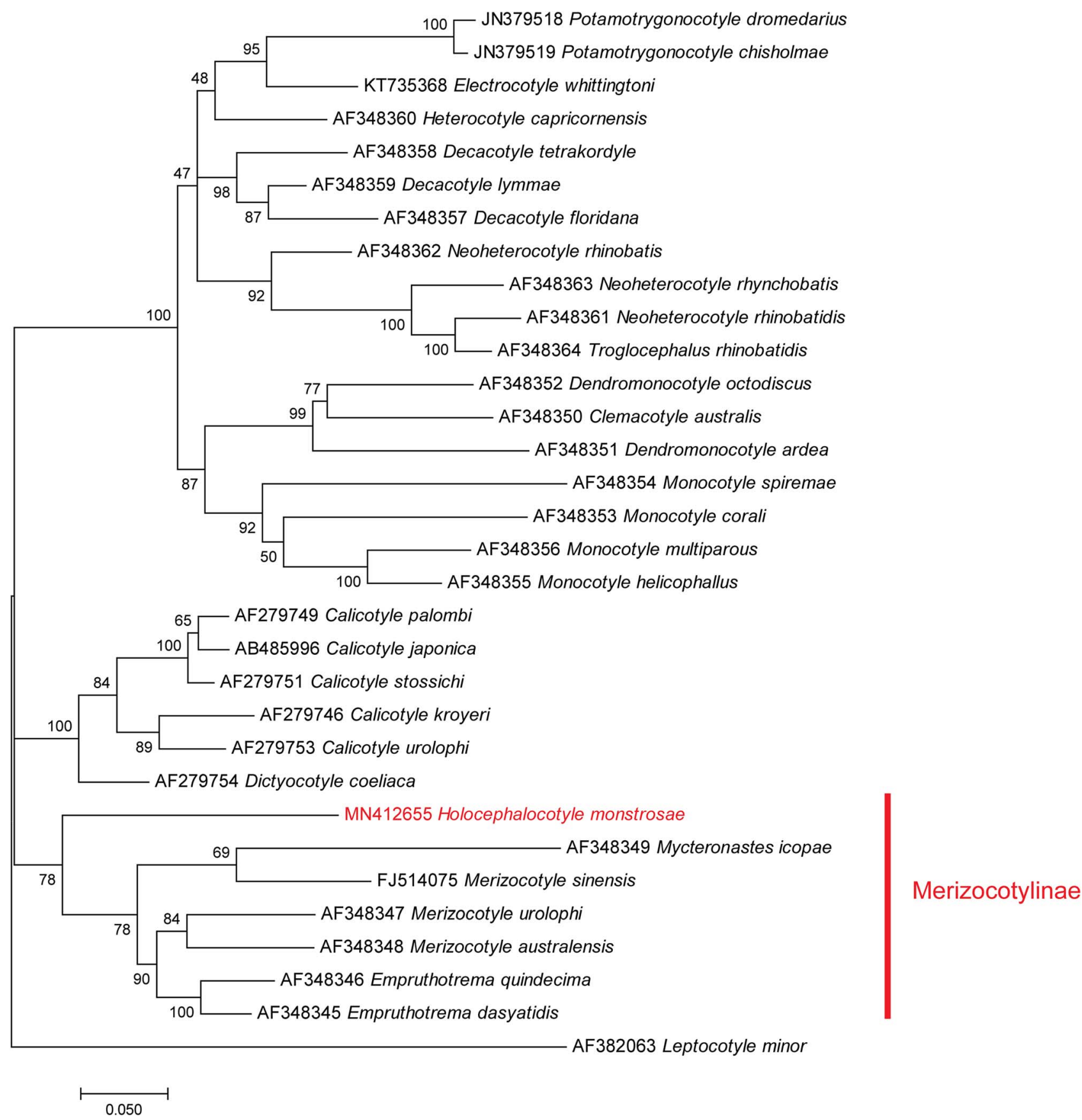

Figure 1. Maximum Likelihood tree of the Monocotylidae based on an analysis of 28S rDNA sequences. Bootstrap percentages with 200 replicates.

$(321-715, n=5)(m)$ at level of ovary. Haptor longer than broad, $346(253-402, n=8)(c), 420(350-558, n=5)(m)$ long; $297(231-334, n=8)(c), 375(436-340, n=5)(m)$ wide. Haptor with one central, five peripherals, and seven interperipheral loculi. Anchor robust (Fig. 2F) $199 \pm 23(147-257, n=51)$ (c), $205(181-224, n=7)(m)$ long with bilaterally flattened handle and curved blade. Fourteen (seven pairs) marginal uncinuli with straight shaft and sickle (Fig. 2G) $13 \pm 1$ $(11-16, n=52)(c), 13(12-14, n=7)(m)$ long; uncinuli distribution as shown in Figure 2A.
Three openings containing what appears to be needlelike secretion open on each side of ventrolateral margin of anterior end. Anterior glands indistinct. Pharynx ovate $107 \pm 27$ $(93-190, n=40)(c), 145(117-190, n=4)(m)$ long, $92 \pm 23(80-150, n=40)(c), 136(115-180, n=4)(m)$ wide; Pharyngeal glands present; Oesophagus short.

Testis oval, $307 \pm 93(110-480, n=37)(c), 345(337-350$, $n=2)(m)$ long, $181 \pm 64(100-350, n=37)(c), 159(157-160$, $n=2)(m)$ wide. Vas deferens arises from left side of testis, runs anteriorly dorsal to transverse vitelline duct. Vas deferens 

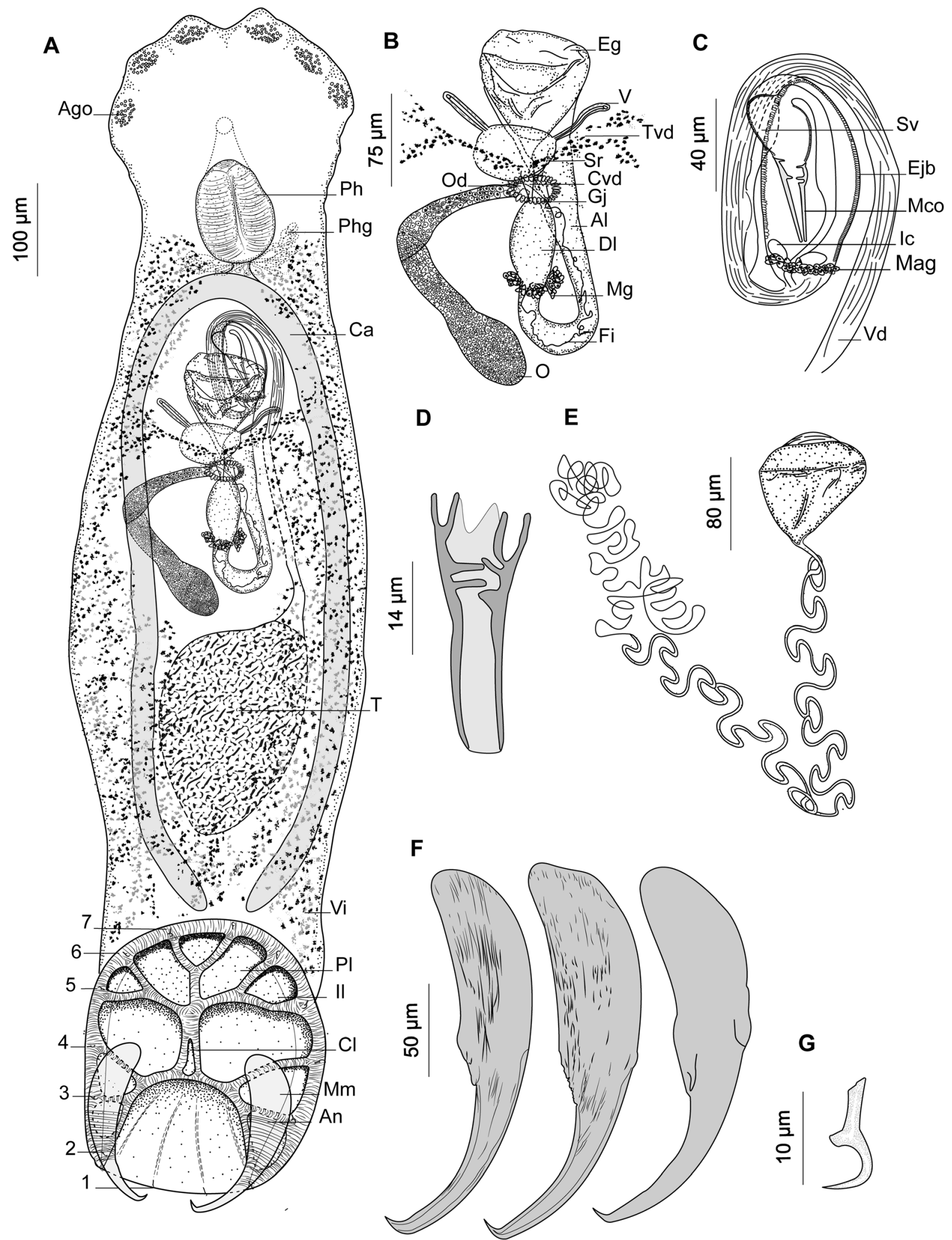

Figure 2. Holocephalocotyle monstrosae n. gen. n. sp. from Chimaera monstrosa. (A) Holotype, whole body (Ago, anterior gland duct openings; Ph, pharynx; Phg, pharyngeal glands; Ca, caecum; T, testis; Vi, vitellarium; Pl, peripheral loculus; Il, interperipheral loculus; $\mathrm{Cl}$, central loculus; Mm, marginal membrane; An, anchor); (B) holotype, female reproductive system (Eg, egg; V, vaginae; Tvd, transverse vitelline duct; Sr, seminal receptacle; Cvd, common vitelline duct; Od, oviduct; Gj, glandular junction; Al, ascending limb of oötype; Dl, descending limb of oötype; Mg, Mehlis' glands; Fi, filament; O, ovary); (C) holotype, male reproductive system, (testis not depicted [Sv, seminal vesicle; Ejb, ejaculatory bulb; Mco, male copulatory organ; Ic, internal chamber; Mag, male accessory glands; Vd, vas deferens]); (D) male copulatory organ; (E) egg; (F) anchors, variations according to different specimens; (G) uncinulus; (1-7) uncinuli. 
inflates to form seminal vesicle and curves ventral to ejaculatory bulb to right side of the body (Fig. 2C). Seminal vesicle runs posteriorly, narrows and enters posterior part of ejaculatory bulb. Ejaculatory bulb muscular elongate $119(56-235, n=25)$ (c), $210(210-210, n=1)(m)$ long, $43(20-91, n=25)(c)$, $40(n=1)(m)$ wide, with two distinct internal chambers (Fig. 2B). Male accessory glands lateral on either side of posterior end of the ejaculatory bulb. MCO (Fig. 2D) $45.1 \pm 5.2(35-58, n=34)(c), 42(40-45, n=4)(m)$ long, sclerotised, funnel shaped and distally compartmentalised.

Ovary loops right intestinal caecum dorsoventrally and narrows to form oviduct (Fig. 2B). Oviduct receives duct from vagina and common vitelline ducts in glandular junction. Ovovitelline duct runs posteriorly to join oötype. Mehlis' glands at base of descending limb of oötype. Oötype forms short descending and ascending limbs and widens at anterior end. Vaginal pores open at level posterior to common genital pore. Two vaginal canals running parallel to transverse vitelline duct to connect seminal receptacle.

Vitellarium extends from level of posterior part of pharynx to posterior part of body proper. Transverse vitelline duct at level of anterior portion of ovary. Egg tetrahedral with long filament (Fig. 2E) $80(60-100, n=20)(c), 95(90-100$, $n=2)(m)$ long, $63.5(44-90, n=20)(c), 75(70-80, n=2)$ (m) wide.

\section{Differential diagnosis}

Holocephalocotyle monstrosae n. gen. n. sp. can be differentiated from the other species of the 29 genera within the Monocotylidae on the basis of the arrangement of the haptoral loculi. The haptoral loculi have a distinctive pattern in which the interperipheral loculi are partially inserted between peripheral loculi (Fig. 2). This feature cannot be accommodated into any of the established genera in the Monocotylidae.

According to the presence of three distinct apertures on each side of the anterior margin into which open ducts from the lateral glands containing a needle-like secretion together with oötype with a descending and ascending limb, we place the parasite of Chimaera monstrosa among the Merizocotylinae [13]. Within this subfamily this parasite has a very unique haptor, which allows it to be considered a new species, type of a new genus. This feature was included in the diagnosis of the subfamily to accommodate this new species in a new genus. The amendment of the subfamily was supported by the phylogenetic tree. With the erection of Holocephalocotyle n. gen., the number of genera belonging to the Monocotylidae increases to 30 .

\section{Discussion}

Interperipheral loculi of Holocephalocotyle monstrosae may represent marginal loculi that have been shifted between the peripheral loculi. In the absence of a phylogenetic analysis conducted using morphological characters, homology of these characters cannot be assumed.

Based on a phylogeny generated from morphological data, Chisholm et al. [11] recognised five genera among the
Merizocotylinae Johnston \& Tiegs, 1922: Merizocotyle Cerfontaine, 1894; Cathariotrema Johnston \& Tiegs, 1922; Empruthotrema Johnston \& Tiegs, 1922; Squalotrema Kearn \& Green, 1983 and Triloculotrema Kearn, 1993. This analysis failed to demonstrate synapomorphies for Merizocotyle (sensu Cerfontaine), Mycteronastes Kearn \& Beverley-Burton, 1990 and Thaumatocotyle Odhner, 1910 so the three genera were synonymised with the senior Merizocotyle.

Chisholm et al. [10] provided a phylogenetic analysis of the Monocotylidae inferred from 28S rDNA and concluded that Merizocotyle was paraphyletic and suggested that Mycteronastes and Thaumatocotyle should perhaps be resurrected as valid genera. Neifar et al. [35], de Buron \& Euzet [15], and Marie \& Justine [30] recognised Thaumatocotyle as a valid genus. Kritsky et al. [24] resurrected Mycteronastes and amended the diagnosis of this genus.

The resurrection of Thaumatocotyle and Mycteronastes seems to be supported by host-parasite phylogenetic relationships. Species of Merizocotyle (sensu Cerfontaine) are usually parasites of Rajidae, members of Thaumatocotyle are all parasites of Dasyatidae, and members of Mycteronastes are parasites of Rhinopristiformes (as proposed by [1, 31]). Merizocotyle urolophi, a parasite of Urolophus paucimaculatus (Urolophidae), may represent a separate genus, as suggested by Chisholm \& Whittington [14], but closely related to Thaumatocotyle as shown by the current phylogeny.

The position of Merizocotyle sinensis is enigmatic. This species is a parasite of Platyrhina sinensis, a Rhinobatidae and not a Dasyatidae as indicated by Chisholm \& Whittington [13]. It has a haptor with seven peripheral loculi like the other species of Merizocotyle (sensu Cerfontaine), but our phylogenetic analysis, based on a partial 28S rDNA unpublished sequence deposited in GenBank, placed this species as a sister-group to Mycteronastes icopae, and not with the two other species of Merizocotyle (Fig. 1); if Merizocotyle sinensis is kept in Merizocotyle, Merizocotyle is not monophyletic based on our analysis. Merizocotyle sinensis might represent a distinct genus as suggested by Kritsky et al. [24].

Our distance analysis also showed that the sequence of the partial 28S rDNA of Holocephalocotyle monstrosae is distinct from all other monocotylids by a significant distance (15.5-23\%). Our phylogenetic analysis based on partial $28 \mathrm{~S}$ sequences confirmed that it is a member of the Merizocotylinae, and that it was the sister-group of the other species of Merizocotylinae included in the analysis; however, available sequences of Merizocotylinae included only members of three genera, Mycteronastes, Merizocotyle and Empruthotrema, which constitute only a subset of the seven genera previously known in this subfamily.

The ejaculatory bulb of Holocephalocotyle monstrosae has two internal chambers. These chambers were also reported from the Calicotylinae [9], Heterocotylinae [34], Euzetiinae [14, 38] and numerous merizocotylines (e.g., Cathariotrema selachii [33] and Mycteronastes caalusi Kritsky, 2017, in which they were described as prostatic reservoirs). This character is not always visible and should be checked for other monocotylids.

The microhabitat seems to have an important impact on the evolution of monocotylids [12]. Holocephalocotyle monstrosa and the other Merizocotylinae are mainly parasites of the nasal 


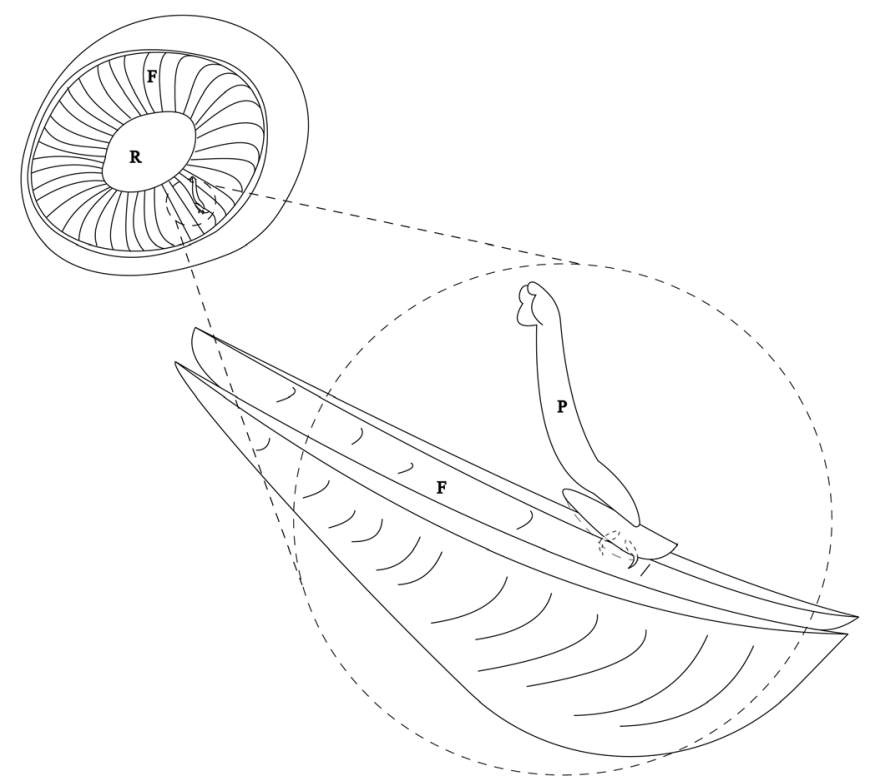

Figure 3. Mode of attachment of Holocephalocotyle monstrosae n. gen. n. sp. in the olfactory fold. F, Fold; R, Raphe; P, Parasite.

cavity. Locations of merizocotylines in other microhabitats than the nasal cavity have been widely discussed by Chisholm \& Whittington [13] and might be erroneous. Species of Calicotylinae have been described from the cloaca, rectum, rectal gland, spiral valve, oviduct and inner wall of the body cavity [9]. Species of the other subfamilies, Dasybatotreminae, Decacotylinae, Heterocotylinae, Monocotylinae and Euzetiinae, were reported from different microhabitats such as the skin and gills.

The haptor of Holocephalocotyle monstrosae attaches to the free edge of the primary nasal fold by folding longitudinally and embedding the blade of the anchors into secondary folds (Fig. 3). Holocephalocotyle monstrosae does not attach to the glass of the Petri dish by its haptor but rather the haptor remains folded with the blades of the anchors protruding. The same mode of attachment was observed for Monocotyle corali [8], a gill parasite of Pastinachus sephen. Presence of the loculi and attachment by folding ensure effective anchoring for $H$. monstrosae. The olfactory rosette is exposed to a strong water current. Howard [20] estimated that $20-50 \%$ of inspired flow of respiratory water passes through secondary folds of the olfactory rosette and then passes into the gills. It remains to be studied how the parasitism by Holocephalocotyle monstrosae may affect the respiratory efficiency of the host.

Acknowledgements. We honour the memory of Professor Louis Euzet who proposed the choice of this host for parasitological studies. The authors would also like to thank all fishing masters in Algiers (Algeria), for their help in collecting biological material.

\section{Conflict of interest}

The Editor-in-Chief of Parasite is one of the authors of this manuscript. COPE (Committee on Publication Ethics, http:// publicationethics.org), to which Parasite adheres, advises special treatment in these cases. In this case, the peer-review process was handled by an Invited Editor, Jérôme Depaquit.

\section{References}

1. Amaral CR, Pereira F, Silva DA, Amorim A, de Carvalho EF. 2018. The mitogenomic phylogeny of the Elasmobranchii (Chondrichthyes). Mitochondrial DNA Part A, 29(6), 867-878.

2. Ayadi ZEM, Gey D, Justine JL, Tazerouti F. 2017. A new species of Microcotyle (monogenea: Microcotylidae) from Scorpaena notata (Teleostei: Scorpaenidae) in the Mediterranean Sea. Parasitology International, 66(2), 37-42.

3. Boudaya L, Neifar L. 2016. Triloculotrema euzeti n. sp. (Monogenea, Monocotylidae) from the nasal tissues of the blackspotted smooth-hound Mustelus punctulatus (Carcharhiniformes, Triakidae) from off Tunisia. Parasite, 23, 62.

4. Bouguerche C, Gey D, Justine JL, Tazerouti F. 2019. Microcotyle visa n. sp. (Monogenea: Microcotylidae), a gill parasite of Pagrus caeruleostictus (Valenciennes) (Teleostei: Sparidae) off the Algerian coast, Western Mediterranean. Systematic Parasitology, 96(2), 131-147.

5. Bouguerche C, Gey D, Justine JL, Tazerouti F. 2019. Towards the resolution of the Microcotyle erythrini species complex: description of Microcotyle isyebi n. sp. (Monogenea, Microcotylidae) from Boops boops (Teleostei, Sparidae) off the Algerian coast. Parasitology Research, 118(5), $1417-1428$.

6. Chaabane A, Justine JL, Gey D, Bakenhaster MD, Neifar L. 2016. Pseudorhabdosynochus sulamericanus (Monogenea, Diplectanidae), a parasite of deep-sea groupers (Serranidae) occurs transatlantically on three congeneric hosts (Hyporthodus spp.), one from the Mediterranean Sea and two from the western Atlantic. PeerJ, 4, e2233.

7. Chaabane A, Neifar L, Gey D, Justine JL. 2016. Species of Pseudorhabdosynochus (Monogenea, Diplectanidae) from groupers (Mycteroperca spp., Epinephelidae) in the Mediterranean and Eastern Atlantic Ocean, with special reference to the "beverleyburtonae group" and description of two new species. PloS One, 11(8), e0159886.

8. Chisholm LA. 1998. A revision of Monocotyle Taschenberg, 1878 (Monogenea: Monocotylidae) with descriptions of three new species from Australia. Journal of Natural History, 32(9), 1259-1290.

9. Chisholm LA, Hansknecht TJ, Whittington ID, Overstreet RM. 1997. A revision of the Calicotylinae Monticelli, 1903 (Monogenea: Monocotylidae). Systematic Parasitology, 38(3), 159-183.

10. Chisholm LA, Morgan JA, Adlard RD, Whittington ID. 2001. Phylogenetic analysis of the Monocotylidae (Monogenea) inferred from $28 \mathrm{~S}$ rDNA sequences. International Journal for Parasitology, 31(11), 1253-1263.

11. Chisholm LA, Wheeler TA, Beverley-Burton M. 1995. A phylogenetic analysis and revised classification of the Monocotylidae Taschenberg, 1879 (Monogenea). Systematic Parasitology, 32(3), 159-191.

12. Chisholm LA, Whittington ID. 1998. Morphology and development of the haptors among the Monocotylidae (Monogenea). Hydrobiologia, 383(1-3), 251.

13. Chisholm LA, Whittington ID. 1999. A revision of the Merizocotylinae Johnston and Tiegs, 1922 (Monogenea: Monocotylidae) with descriptions of new species of Empruthotrema Johnston and Tiegs, 1922 and Merizocotyle Cerfontaine, 1894. Journal of Natural History, 33(1), 1-28. 
14. Chisholm LA, Whittington ID. 2001. Euzetia occultum n. g., n. sp. (Euzetiinae n. subf.), a monocotylid monogenean from the gills of Rhinoptera neglecta (Rhinopteridae) from Moreton Bay, Queensland, Australia. Systematic Parasitology, 48(3), 179-183.

15. de Buron I, Euzet L. 2005. A new species of Thaumatocotyle (Monogenea: Monocotylidae) from Dasyatis sabina (Myliobatiformes: Dasyatidae) off the coast of South Carolina. Journal of Parasitology, 91(4), 791-793.

16. Dienske H. 1968. A survey of the metazoan parasites of the rabbit-fish, Chimaera monstrosa L. (Holocephali). Netherlands Journal of Sea Research, 4(1), 32-58.

17. Ferrando S, Gallus L, Ghigliotti L, Amaroli A, Abbas G, Vacchi M. 2017. Clarification of the terminology of the olfactory lamellae in Chondrichthyes. Anatomical Record, 300 (11), 2039-2045.

18. Gaevskaya AV. 2002. Spinoplagioporus minutus (Trematoda, Enenteridae), a parasite of chimaeras (Chimaeriformes) from the Atlantic Ocean. Vestnik Zoologii, 36(6), 69-71.

19. Hassouna N, Michot B, Bachellerie JP. 1984. The complete nucleotide sequence of mouse $28 \mathrm{~S}$ rRNA gene. Implications for the process of size increase of the large subunit rRNA in higher eukaryotes. Nucleic Acids Research, 12(8), 3563-3583.

20. Howard LE, Holmes WM, Ferrando S, Maclaine JS, Kelsh RN, Ramsey A, Abel RL, Cox JPL. 2013. Functional nasal morphology of chimaerid fishes. Journal of Morphology, 274 (9), 987-1009.

21. Justine JL. 2005. Species of Pseudorhabdosynochus Yamaguti, 1958 (Monogenea: Diplectanidae) from Epinephelus fasciatus and E. merra (Perciformes: Serranidae) off New Caledonia and other parts of the Indo-Pacific Ocean, with a comparison of measurements of specimens prepared using different methods, and a description of $P$. caledonicus n. sp. Systematic Parasitology, 62(1), 1-37.

22. Kheddam H, Justine JL, Tazerouti F. 2016. Hexabothriid monogeneans from the gills of deep-sea sharks off Algeria, with the description of Squalonchocotyle euzeti n. sp. (Hexabothriidae) from the kitefin shark Dalatias licha (Euselachii, Dalatiidae). Helminthologia, 53(4), 354-362.

23. Kodádková A, Bartošová-Sojková P, Holzer AS, Fiala I. 2015. Bipteria vetusta $\mathrm{n}$. sp. an old parasite in an old host: tracing the origin of myxosporean parasitism in vertebrates. International Journal for Parasitology, 45(4), 269-276.

24. Kritsky DC, Bullard SA, Bakenhaster MD, Scharer RM, Poulakis GR. 2017. Resurrection of Mycteronastes (Monogenoidea: Monocotylidae), with description of Mycteronastes caalusi n. sp. from olfactory sacs of the smalltooth sawfish, Pristis pectinata (Pristiformes: Pristidae), in the Gulf of Mexico off Florida. Journal of Parasitology, 103(5), 477-485.

25. Kritsky DC, Bullard SA, Ruiz CF, Warren MB. 2017. Empruthotrema longipenis $\mathrm{n}$. sp. (Monogenoidea: Monocotylidae: Merizocotylinae) from the olfactory sacs of the smooth butterfly ray Gymnura micrura (Bloch \& Schneider) (Myliobatiformes: Gymnuridae) in the Gulf of Mexico. Systematic Parasitology, 94(7), 777-784.

26. Kumar S, Stecher G, Tamura K. 2016. MEGA7: molecular evolutionary genetics analysis version 7.0 for bigger datasets. Molecular Biology and Evolution, 33(7), 1870-1874.
27. Licht M, Schmuecker K, Huelsken T, Hanel R, Bartsch P, Paeckert M. 2012. Contribution to the molecular phylogenetic analysis of extant holocephalan fishes (Holocephali, Chimaeriformes). Organisms Diversity \& Evolution, 12(4), 421-432.

28. Lynch JE. 1945. Redescription of the species of Gyrocotyle from the ratfish, Hydrolagus colliei (Lay and Bennet), with notes on the morphology and taxonomy of the genus. Journal of Parasitology, 31(6), 418-446.

29. Malmberg G. 1970. The excretory systems and the marginal hooks as a basis for the systematics of Gyrodactylus (Trematoda, Monogenea). Arkiv for Zoologi, 23(1/2), 1-235.

30. Marie AD, Justine JL. 2006. Thaumatocotyle pseudodasybatis Hargis, 1955 (Monogenea: Monocotylidae) from Aetobatus cf. narinari, with a comparison of specimens from Australia, French Polynesia and New Caledonia. Systematic Parasitology, 64(1), 47-55.

31. Naylor GJ, Caira JN, Jensen K, Rosana KA, Straube N, Lakner C. 2012. Elasmobranch phylogeny: a mitochondrial estimate based on 595 species. Biology of Sharks and their Relatives, 2, 31-56.

32. Nei M, Kumar S. 2000. Molecular evolution and phylogenetics. New York, NY: Oxford University Press.

33. Neifar I, Euzet L. 1996. Presence in the Mediterranean Sea of the genus Cathariotrema (Monogenea, Monocotylidae), a parasite of the nasal cavity of Galeorhinus galeus (Pisces, Selachii). Parazitologia, 38, 46.

34. Neifar L, Euzet L, Ben Hassine OK. 1999. Trois nouveaux Heterocotyle (Monogenea, Monocotylidae) parasites branchiaux de Taeniura grabata (Euselachii, Dasyatidae) en Tunisie. Zoosystema, 21(2), 157-170.

35. Neifar L, Euzet L, Hassine OKB. 2000. New species of the Monocotylidae (Monogenea) from the stingray Dasyatis tortonesi Capapé (Euselachii, Dasyatidae) off the Tunisian coast, with comments on host-specificity and the specific identities of Mediterranean stingrays. Systematic Parasitology, 47(1), 43-50.

36. Olsson P. 1896. Sur Chimaera monstrosa et ses parasites. Mémoires de la Société Zoologique de France, 9, 499-512.

37. Pariselle A, Euzet L. 1995. Gill parasites of the genus Cichlidogyrus Paperna, 1960 (Monogenea, Ancyrocephalidae) from Tilapia guineensis (Bleeker, 1862), with descriptions of six new species. Systematic Parasitology, 30(3), 187-198.

38. Pulido-Flores G, Monks S. 2008. A new species of Euzetia (Monogenea: Monocotylidae) on the gills of Rhinoptera bonasus (Rhinopteridae) from Ciudad del Carmen, Campeche. México: Revista Mexicana de Biodiversidad. p. 79.

39. Ratnasingham S, Hebert PD. 2007. The Barcode of Life Data System (http://www.barcodinglife.org). Molecular Ecology Notes, 7(3), 355-364.

40. Ruszkowski JS. 1934. Sur les vers parasites des chimères. Annales de Parasitologie Humaine et Comparée, 12(6), 482491.

41. Ward RD, Zemlak TS, Innes BH, Last PR, Hebert PD. 2005. DNA barcoding Australia's fish species. Philosophical Transactions of the Royal Society B: Biological Sciences, 360(1462), $1847-1857$

Cite this article as: Derouiche I, Neifar L, Gey D, Justine J-L and Tazerouti F. 2019. Holocephalocotyle monstrosae n. gen. n. sp. (Monogenea, Monocotylidae) from the olfactory rosette of the rabbit fish, Chimaera monstrosa (Holocephali, Chimaeridae) in deep waters off Algeria. Parasite 26, 59. 
Reviews, articles and short notes may be submitted. Fields include, but are not limited to: general, medical and veterinary parasitology; morphology, including ultrastructure; parasite systematics, including entomology, acarology, helminthology and protistology, and molecular analyses; molecular biology and biochemistry; immunology of parasitic diseases; host-parasite relationships; ecology and life history of parasites; epidemiology; therapeutics; new diagnostic tools.

All papers in Parasite are published in English. Manuscripts should have a broad interest and must not have been published or submitted elsewhere. No limit is imposed on the length of manuscripts.

Parasite (open-access) continues Parasite (print and online editions, 1994-2012) and Annales de Parasitologie Humaine et Comparée (1923-1993) and is the official journal of the Société Française de Parasitologie. 